\title{
Research on The Antioxidant Efficiacy of Olive (Olea Europaea L.) Leaf Using by in vitro Methods
}

\author{
Süleyman Muammer ERDOĞAN¹, Esra AKKOL², Gülcan AVCI* \\ ${ }^{1}$ Afyon Kocatepe University Veterinary Faculty Biochemistry Department, Afyonkarabisar, Turkey \\ ${ }^{2}$ Gazi University Pharmacy Faculty Pharmacognosy Department, Ankara, Turkey
}

\begin{abstract}
In this study, antioxidant properties of olive (Olea europaea L.) leaves containing oleuropein were investigated in $n$ hexane, ethyl acetate, and methanol based extracts obtained from dried olive leaves at different concentration by various in vitro methods. Percentage yields of the O. europaea were found for the $n$-hexane extract $13.21 \%$, for ethyl acetate extract $26.15 \%$ and for methanol extract $34.59 \%$, respectively. Total phenolic substance content $(85.27 \pm 15.03 \%)$, linoleic acid reduction $(89.52 \pm 9.77 \%)$ and reduction capacity $(1.49 \pm 0.03)$ were the highest in the methanol extract. Finally, the DPPH radical scavenging efficiency $(72.93 \pm 0.42 \%)$, reduction of iron (II) ions $(50.53 \pm 5.53 \%)$ and superoxide radical scavenging activity $(72.93 \pm 0.42 \%)$. were the highest in the ethyl acetate extract. In conclusion, it was seen that total phenolic substances, linoleic acid reduction and reduction capacity of the methanol extract of the antioxidant activity of the O. europaea was more active when equated with $n$-hexane and ethyl acetate extracts. Also, it was found out that the ethyl acetate extract was more effective in DPPH radical scavenging, iron reduction, linoleic acid reduction and superoxide radical scavenging activity. According to the data obtained, it is thought that olive leaf might be evaluated as a natural and cheap alternative antioxidant in different fields such as food, cosmetic, pharmaceutical industry and animal nutrition.
\end{abstract}

Keywords: Antioxidant activity, Olea europaea L., Oleaceae, Olive, Total phenolic substance

\section{Zeytin (Olea Europea L.) Yaprağının Antioksidan Etkilerinin in vitro Yöntemlerle Araştırılması}

\section{ÖZ}

Bu çalışmada pek çok sekonder metabolitin yanında major madde olarak oleuropein içeren zeytin (Olea europaea L.) yaprağından elde edilen edilen $n$-hekzan, etil asetat ve metanol ekstrelerin farklı konsantrasyonlardaki antioksidan aktiviteleri çeșitli in vitro yöntemlerle incelenmiştir. Zeytin yaprağının $n$-hekzan, etil asetat ve metanollü ekstrelerinin yüzde verimleri sırasılyla \%13.21, 26.15 ve $\% 34.59$ olarak bulunmuştur. Toplam fenolik madde içeriği $(85.27 \pm 15.03 \%)$, linoleik asit indirgeme $(89.52 \pm 9.77 \%)$ ve indirgenme kapasitesi (1.49 \pm 0.03$)$ methanol ekstresinde en yüksek idi. Son olarak, DPPH radikali süpürücü aktivitesi $(72.93 \pm 0.42 \%)$, demir (II) iyonlarını indirgeme $(50.53 \pm 5.53 \%)$ ve süperoksit radikali giderme aktivitesi $(72.00 \pm 1.35 \%)$ etil asetat ekstresinde en yüksekti. Sonuç olarak zeytin yaprağının metanollü ekstresinde toplam fenolik madde, linoleik asit indirgeme ve indirgenme kapasitesi diğer ekstrelere göre daha aktif bulunmuştur. DPPH radikali tutma, demir (II) şelatlama ve süperoksit radikali giderme aktivitesinde ise etil asetat ekstresinin daha etkili olduğu tespit edilmiştir. Elde edilen veriler doğrultusunda, zeytin yaprağının gıda, kozmetik, ilaç endüstrisi ve hayvan besleme gibi alanlarda doğal alternatif bir antioksidan olarak değerlendirilebileceği düşünülmektedir.

Anahtar Kelimeler: Antioksidan aktivite, Olea europaea L., Oleaceae, Toplam fenolik madde, Zeytin

To cite this article: Ava G. Erdoğan S.M. Ake.ol E. Research on The Antioxidant Efficiacy of Olive (Olea Europaea L.) Leaf Using by in vitro Methods\#. Kocatepe Vet J. (2020) 13(3):319-326 


\section{INTRODUCTION}

Olive and olive products have important place from in terms of Turkey economy, in which ranks $4^{\text {th }}$ in the field of olive cultivation among the world countries (Keser and Bilal 2010). In Turkey, olive leaves remaining after harvesting the fruits are generally to be destroyed by burned due to they are waste. Investigations for evaluation of the biological activity have revealed that leaves of this plant to possess antibacterial, antifungal and antioxidant properties (Benavente-García et al. 2000, Ferreira et al. 2007, Lee et al. 2010). Olive, a valuable plant in terms of nutritional value, contains water (50\%), lipid (22\%), protein (1.6\%), sugar (19.1\%), cellulose $(5.8 \%)$, minerals, hydrocarbons, tocopherols and polyphenols (Kiritsakis 1998). Olive leaf also contains high functional value phenolic compounds (tyrosol, coumaric acid, hydroxytyrosol, gallic acid, caffeic acid, ferulic acid), flavonoids (luteolin, quercetin, catechin, apigenin) and secoiridoids (oleuropein, ligstrocyte) (Dekanski et al. 2009, Talhaoui et al. 2015). Oleuropein, which causes bitter and acrid aroma of olive, is the main component of olive tree (Silva et al. 2006) and has antioxidant, antimicrobial, antiviral, anti-inflammatory, antiatrogenic, hypolipidemic, antiaging, and parkinson, alzheimer, skin, heart and cancer-protective effects (Ferreira et al. 2007, Omar 2010, Barbora et al. 2014).

Olive leaf extracts are used primarily in animal nutrition and biomass energy. In addition, it is assumed that presence of excessive level of cardiotonic substance oleanolic acid in olive leaves may prove it beneficial for hypertesnive associated cardiac arrests (Somove et al. 2003).

Leaves of olive usage in the food, cosmetics and pharmaceutical industry is becoming increasingly common (Spinelli et al. 2010, Rodrigues et al. 2015, Souilem et al. 2017). Although there are studies to reveal different biological effects of olive, which have been reported to have anti-inflammatory, antiallergic, antibacterial, antimycotic, immunoregulator, antidiabetic and hypolipemic effects (Omar 2010), researches on in vitro or in vivo effects of olive leaves are quite insufficient.

The objective of this study is to investigate the antioxidant properties of $n$-hexane, ethyl acetate and methanol based extracts obtained from olive leaves using in vitro methods.

\section{MATERIALS and METHODS}

\section{Plant material}

Olea europaea L. (Oleaceae) leaves were acquired from Selçuk district of İzmir province, Turkey in December 2017. The leaf samples after collection were first verified a by Prof. Dr. Esra Akkol, Department of Pharmacognosy, Faculty of Pharmacy, Gazi University, Ankara, Turkey and were deposited in the Herbarium of same Faculty.

\section{Preparation of extracts}

Leaves $(400 \mathrm{~g})$ of $O$. europea were grinded after comlete shade-driying. The grounded powder was later extracted with $2000 \mathrm{~mL}$ n-hexane, ethyl acetate and methanol each, for 5 days at room temperature. The collected extracts were first strained and later vaporized under low pressure at $40^{\circ} \mathrm{C}$ till there were completely dried. The percentage yields of each extract were calculated and were found to be $13.21 \%$ for $n$-hexane, $26.15 \%$ for ethyl acetate, and $34.59 \%$ for methanol, respectively.

\section{HPLC analysis}

The high-performance liquid chromatography (HPLC) analysis was conducted by using 1200 series HPLC system by Agilent Technologies (Palo Alto, CA, USA) according to method as described by Ansari et al. (2006). The system consisted of a quaternary pump, in-line degasser, column thermostat, and ultraviolet detector. Agilent Chemstation software was used for the data processing and acquisition. The chromatographic separation of the fractions was performed by a LiChrospher ${ }^{\circledR} 100$ RP C-18 (film thickness, $5 \mu \mathrm{m} ; 250$ $\times 4.0 \mathrm{~mm}$ ) (Supelco Inc., Bellefonte, PA, USA) column using an isocratic elution of HPLC-grade water adjusted to $\mathrm{pH} 2.5$ with o-phosphoric acid:acetonitrile $\quad(80: 20 \quad \mathrm{vol} / \mathrm{vol})$. Detection wavelength was $280 \mathrm{~nm}$, and the flow rate was optimized at $1 \mathrm{~mL} /$ minute. The stock solution (1 $\mathrm{mg} / \mathrm{mL}$ ) of oleuropein (Chromadex, Irvine, CA, USA) was prepared by dissolving it in HPLC-graded water and was used as reference. The calibration curve was achieved by diluting the stock seven times, and the equation was designed. The methanol extract was solubilized in methanol, while ethyl acetate extract was liquefied in a small quantity of ethyl acetate and then diluted with isopropanol to the desired volume. Oleuropein and the all other extracts were filtered by using a membrane filter (pore size, $0.45 \mu \mathrm{m})$. The reference compound and diluted extracts were inoculated for evaluation of their oleuropein concentration.

\section{In vitro antioxidant property tests Estimation of total phenolic substances}

The overall phenolic substances of olive leaf extracts were measured using Folin-Ciocalteu's phenol reagent (FCR) as described by Singleton and Rossi (1965). The principle of this method rely on the formation of a blue colored compound as a result of the phenolic substances reducing FCR. The absorbance of blue compound is recordedat $760 \mathrm{~nm}$. The total phenolic substances of olive leaf extracts are presented in terms of $\mathrm{mg}$ gallic acid equivalents (GAE) per $\mathrm{g}$ of extract.

The gallic acid was used as standard solution. $0.5 \mathrm{~mL}$ of test extracts solution was stirred along with $0.5 \mathrm{~mL}$ FCR and incubated for 3 minutes. Then, $2 \% \mathrm{Na}_{2} \mathrm{CO}_{3}$ 
was added and stored at room temperature for $2 \mathrm{~h}$. After incubation period, the absorbance of reaction mixture was recorded at $760 \mathrm{~nm}$ against distilled water by using as blank. The results were computed by using the standard calibration curve of gallic acid $(62.5-1000 \mu \mathrm{g} / \mathrm{mL})$ and were demonstrated in terms of gallic acid equivalents (GAE $\mu \mathrm{g} / \mathrm{g}$ ).

\section{Evaluation of DPPH radical scavenging activity}

The DPPH scavenging activity of olive leaf extracts was established by using the technique of Blois (1958). The method works on the principle of removing DPPH, which is a stable free radical and has a dark purple colour. When the DPPH radical is scavenged, the colour of the reaction mixture shifts from purple to yellow and reduces absorbance at 517 nm.

Briefly, 0.5 mL olive leaf extracts (100-250-500-1000 $\mu \mathrm{g} / \mathrm{mL}$ ) were supplemented with DPPH (2 mL, 0.1 $\mathrm{mM})$. Each mixture was placed in the dark for $30 \mathrm{~min}$ and the absorbance was recorded at $517 \mathrm{~nm}$ against ethanol using as blank. $A$ blank is reffered as measure of the absorbance of the control reaction which contains all reagents except test compounds. $A$ sample is measure of the absorbance of the olive leaf extracts only. The percentage of inhibition was calculated against blank.

Inhibition $\%=(A$ blank $-A$ sample $/ A$ blank $) \times 100$

\section{Antioxidant activity with ferric thiocyanate method in linoleic acid system}

Antioxidant activity in a linoleic acid emulsion system was evaluated using the ferric thiocyanate method (Pan et al. 2007). According this method, peroxides, an oxidation product of linoleic acid, oxidize $\mathrm{Fe}^{2+}$ to $\mathrm{Fe}^{3+}$. As a result, a decrease in absorbance reflects increased level of antioxidant activity.

The linoleic acid emulsion was developedby adding $77.5 \mu \mathrm{L}$ of linoleic acid, $87.5 \mathrm{mg}$ of Tween 20 and 25 $\mathrm{ml}$ of phosphate buffer (0.04 M, pH 7.0). Then the mixture was homogenized. Variable concentrations (100-250-500-1000 $\mu \mathrm{g} / \mathrm{mL})$ of olive leaf extracts $(0.5$ $\mathrm{mL})$ were added into linoleic acid emulsion $(1.25 \mathrm{~mL}$, $0.2 \mathrm{M}, \mathrm{pH} 7.0)$ and phosphate buffer $(0.75 \mathrm{~mL}, 0.04$ $\mathrm{M}, \mathrm{pH}$ 7.0). The blend was incubated at $37^{\circ} \mathrm{C}$ which accelerated the peroxidation process. The control composed of linoleic acid and phosphate buffer without adding extracts. After an interval of $24 \mathrm{~h}$ each, the readings were recorded. The mixture 0.05 $\mathrm{mL}$ of misture was removed and mixed thoroughly with $2.35 \mathrm{~mL}$ of $75 \%$ ethanol, $0.05 \mathrm{~mL}$ of $30 \%$ ammonium thiocyanate and after 3 minutes with 0.05 $\mathrm{mL}$ of $20 \mathrm{mM}$ ferrous chloride in $3.5 \% \mathrm{HCl}$. After blendig with all component, the mixture was set out for 5 minutes at room temperature. The levels of peroxidation were calculated by measuring the absorbance at $500 \mathrm{~nm}$.
The percentage of inhibition was determined against control by using following formula:

Inhibition $\%=1-(A$ sample $/$ maximum control $) \times$ 100

Determination of iron (II) ions chelating activity Iron (II) ions chelating activity of olive leaf extracts was performed conferring to protocol described by Dinis et al. (1994). This method works on the principle of inhibition in the formation of ferrous iron-ferrozine complex of chelating agents in the test tube. The decrease in red colour was determined by decrease in absorbance of the ferrous iron-ferrozine complex at $562 \mathrm{~nm}$.

Concisely, altered concentrations of olive leaf extracts $(100-1000 \mu \mathrm{g} / \mathrm{mL})$ in $0.5 \mathrm{~mL}$ were mixed with a solution of $0.6 \mathrm{mM}$ ferrous chloride $(0.05 \mathrm{~mL})$ and kept for $30 \mathrm{~min}$. Later, the mixture was supplemented with ferrozine (5 mM, $0.1 \mathrm{~mL})$. After $10 \mathrm{~min}$, absorbance of the test tubes and EDTA as standards (50-250 $\mu \mathrm{g} / \mathrm{mL}) \quad$ were recorded spectrophotometrically at $562 \mathrm{~nm}$. The control consisted of distilled water only without $\mathrm{FeCl}_{2}$ and ferrozine. The percentageinhibition of iron chelating activity was recorded with following equation:

Inhibition $\%=1-(A$ control $-A$ sample $/ A$ control $) \mathrm{x}$ 100

\section{Measure of superoxide radical scavenging activity}

The superoxide radical scavenging activity works on the principle that the superoxide radical produced by the NADH (nicotinamide adenine dinucleotide)/PMS (phenazine methosulfate) $/ \mathrm{O}_{2}$ complex reduces nitro blue tetrazolium (NBT) from yellow to purplecoloured formazone (Nishimikiet al. 1972). The decrease of the absorbance values indicates consumption of superoxide radical anions.

According to method, $0.5 \mathrm{~mL}$ NBT $(156 \mu \mathrm{M})$ and $\mathrm{NADH}(468 \mu \mathrm{M})$ in the sodium phosphate buffer (20 mM, pH 7.4) were added to different concentrations of extract solutions $(0.5 \mathrm{~mL}, 100-250$ $500-1000 \mu \mathrm{g} / \mathrm{mL})$ in phosphate buffer. The reaction began by supplementation of PMS $(50 \mu \mathrm{L}, 60 \mu \mathrm{M})$ into the reaction mixture and incubated at room temperature for 5 minutes. Then, the absorbance was monitored at $560 \mathrm{~nm}$ against the corresponding distilled water as control.

The percentage of inhibition was calculated by using following formula:

Inbibition $\%=(A$ control $-A$ sample $/ A$ control $) \times$ 100 


\section{Ferric ions reducing antioxidant power}

Reducing capacity of olive leaf extracts was determined according to the developed method Oyaizu (1986). The method is based on $\mathrm{Fe}^{+3}$ ions are reduced to $\mathrm{Fe}^{+2}$ ions. When ferric chloride $\left(\mathrm{FeCl}_{3}\right)$ is added, the absorbance of the complex compound formed in Prussian blue colour is measured at 700 $\mathrm{nm}$. The highest absorption values mean the highest reduction capacity for extracts.

A $0.5 \mathrm{~mL}$ solution of extracts (100-250-500-1000 $\mu \mathrm{g} / \mathrm{mL}$ ) was mixed with $1.25 \mathrm{~mL}$ of phosphate buffer $(0.2 \mathrm{M}, \mathrm{pH}$ 6.6) and $1 \%$ potassium ferricyanide. After incubating at $50^{\circ} \mathrm{C}$ for 20 minutes, the reaction mixture was further supplemented with $1.25 \mathrm{~mL}$ of $10 \%$ trichloroacetic acid and vortexed. The reaction mixture was centrifuged at $2500 \mathrm{rpm}$ for 10 minutes. Later, $1.25 \mathrm{~mL}$ supernatant was collected and mixed with equal volume of distilled water and $0.25 \mathrm{~mL}$ $\mathrm{FeCl}_{3}(0.1 \%)$. It was kept for 10 minutes at room temperature and the absorbances were evaluated at $700 \mathrm{~nm}$ against distilled water as blank.
Antioxidant activity assays was conducted in triplicate. The results obtained were evaluated by SPSS 13.0 and given as mean \pm standard error values. The statistical differences among groups were analysed through One way ANOVA analysis. Duncan test was used as a posthoc test. Statistical significance of all data was determined as $\mathrm{P}<0.05$ level.

\section{RESULTS}

The results obtained with the n-hexane, ethyl acetate and methanol extracts of the leaves of $\mathrm{O}$. europea in the antioxidant activity tests are given in Table 1-6.

The olive leaf extracts were examined for their total phenolic substance amounts (Table 1) according to acquire from standard gallic acid curve graph (Figure 1). The highest phenolic content of methanolic extract was $85.27 \pm 15.03 \mathrm{mg}$ GAE in $1000 \mu \mathrm{g} / \mathrm{mL}$ while the lowest value was $0.18 \pm 1.32 \mu \mathrm{g} \mathrm{GAE} / \mathrm{g}$ extract in n-hexane extract $(500 \mu \mathrm{g} / \mathrm{mL})$.

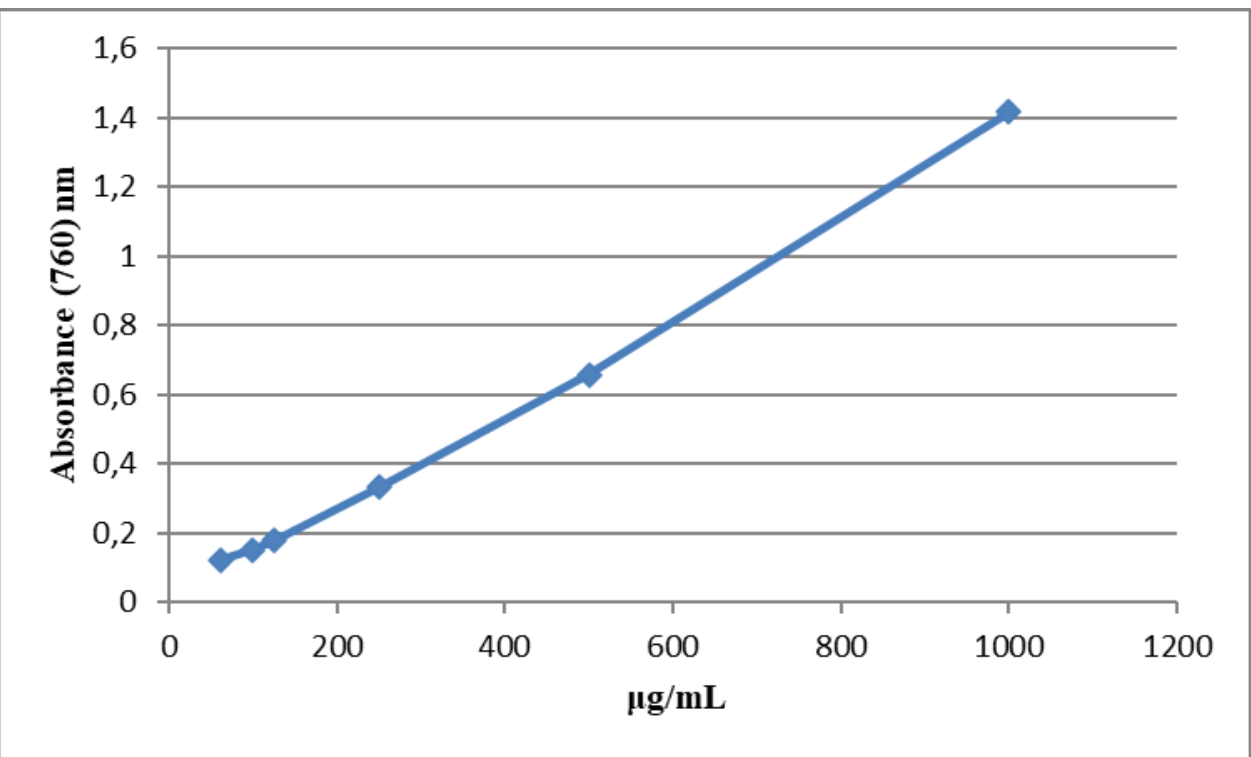

Statistical analysis

Figure 1.Standard gallic acid curve graphic

Table 1. Total phenolic substances concentration of the extracts obtained from O. europea leaves

\section{Total phenolic substances}

Extracts

$(\mu \mathrm{g} \mathrm{GAE} / \mathrm{g} \pm \mathrm{SEM})$

\begin{tabular}{lcccc} 
& $100 \mu \mathrm{g} \mathrm{mL}-1$ & \multicolumn{1}{c}{$250 \mu \mathrm{g} \mathrm{mL}^{-1}$} & $500 \mu \mathrm{g} \mathrm{mL}-1$ & $1000 \mu \mathrm{g} \mathrm{mL}^{-1}$ \\
n-Hexane & $0,4177 \pm 2,34^{\mathrm{d}}$ & $2,79 \pm 0,71^{\mathrm{d}}$ & $0,18 \pm 1,32^{\mathrm{d}}$ & $12,53 \pm 3,82^{\mathrm{cd}} \mathrm{d}$ \\
Ethyl acetate & $13,49 \pm 8,22^{\mathrm{c}, \mathrm{d}}$ & $14,91 \pm 3,59^{\mathrm{c}, \mathrm{d}}$ & $19,89 \pm 2,29^{\mathrm{c}, \mathrm{d}}$ & $33,67 \pm 4,12^{\mathrm{b}, \mathrm{c}}$ \\
Methanol & $11,58 \pm 0,63^{\mathrm{c}, \mathrm{d}}$ & $26,78 \pm 3,14^{\mathrm{c}}$ & $48,39 \pm 1,42^{\mathrm{b}}$ & $85,27 \pm 15,03^{\mathrm{a}}$
\end{tabular}

a,b,c,d Different letters in the same column represent the statistically significant difference between the mean values $\mathrm{P}<0,001$ SEM: Standard error meaning 
The percentages of DPPH inhibition of olive leaf extracts at different concentrations are shown in Table 2. According to the results, DPPH radical scavenging activity was found to be highest in ethyl acetate extract $(72.93 \pm 0.42 \%)$ at a concentration of $500 \mu \mathrm{g} / \mathrm{mL}$, the lowest value in $\mathrm{n}$-hexane extract (100 $\mu \mathrm{g} / \mathrm{mL}$ ) was $13.77 \pm 1.23 \%$.

Table 2. DPPH radical scavenging activity of the extracts obtained from O. europea leaves

\begin{tabular}{|c|c|c|c|c|}
\hline \multirow[t]{2}{*}{ Extracts } & \multicolumn{4}{|c|}{$\begin{array}{c}\text { DPPH radical scavenging activity } \\
\text { (Inhibition } \% \pm \text { SEM) }\end{array}$} \\
\hline & $100 \mu \mathrm{g} \mathrm{mL}^{-1}$ & $250 \mu \mathrm{g} \mathrm{mL}^{-1}$ & $500 \mu \mathrm{g} \mathrm{mL}^{-1}$ & $1000 \mu \mathrm{g} \mathrm{mL}^{-1}$ \\
\hline$n$-Hexane & $13,77 \pm 1,23^{\mathrm{f}}$ & $43,67 \pm 1,04 \mathrm{e}$ & $64,10 \pm 4,95^{\mathrm{a}, \mathrm{b}, \mathrm{c}}$ & $71,17 \pm 2,93^{\mathrm{a}}$ \\
\hline Ethyl acetate & $42,37 \pm 3,34 \mathrm{e}$ & $61,50 \pm 0,79 \mathrm{~b}, \mathrm{c}, \mathrm{d}$ & $68,40 \pm 0,67 \mathrm{a}, \mathrm{b}$ & $72,93 \pm 0,42^{a}$ \\
\hline Methanol & $55,77 \pm 1,58^{\mathrm{c}, \mathrm{d}}$ & $55,67 \pm 2,83 \mathrm{c}, \mathrm{d}$ & $54,43 \pm 5,17 \mathrm{~d}$ & $60,53 \pm 4,33 \mathrm{~b}, \mathrm{c,d}$ \\
\hline
\end{tabular}

a,b,c,d,e,f Different letters in the same column represent the statistically significant difference between the mean values $\mathrm{P}<0,001$ SEM: Standard error meaning

As shown in Table 3, the highest value linoleic acid reduction was obtained as $89.52 \pm 9.77 \%$ in methanolic extract at $250 \mu \mathrm{g} / \mathrm{mL}$ concentration, the lowest value as $61.19 \pm 4.05 \%$ in ethyl acetate extract at $100 \mu \mathrm{g} / \mathrm{mL}$ concentration.

Table 3. Antioxidant activity in linoleic acid system of the extracts obtained from O. europea leaves

\begin{tabular}{lcccc}
\hline \multirow{2}{*}{ Extracts } & \multicolumn{4}{c}{$\begin{array}{c}\text { Antioxidant activity in linoleic acid system } \\
\text { (Inhibition \% } \% \mathbf{~ S E M ) ~}\end{array}$} \\
\cline { 2 - 5 } $\boldsymbol{n}$-Hexane & $100 \mu \mathrm{g} \mathrm{mL} \mathrm{mL}^{-1}$ & $250 \mu \mathrm{g} \mathrm{mL}^{-1}$ & $500 \mu \mathrm{g} \mathrm{mL} \mathrm{mL}^{-1}$ & $1000 \mu \mathrm{g} \mathrm{mL}^{-1}$ \\
Ethyl acetate & $61,19 \pm 4,05^{\mathrm{c}}$ & $63,09 \pm 0,48^{\mathrm{c}}$ & $65,24 \pm 6,67^{\mathrm{c}}$ & $86,67 \pm 7,63^{\mathrm{a}, \mathrm{b}}$ \\
Methanol & $83,57 \pm 2,70^{\mathrm{a}, \mathrm{b}}$ & $89,52 \pm 9,77^{\mathrm{a}}$ & $74,79 \pm 3,93^{\mathrm{a}, \mathrm{b}, \mathrm{c}}$ & $67,67 \pm 2,34^{\mathrm{c}}$ \\
\hline a,b,c Different letters in the same line represent the statistically significant difference between the mean values $\mathrm{P}<0,001$ \\
SEM: Standard error meaning
\end{tabular}

The effects of various amounts of olive leaf extracts on reduction of iron (II) ions are given in Table 4 . While it was found $50.53 \pm 5.53 \%$ in ethyl acetate extract at $1000 \mu \mathrm{g} / \mathrm{mL}$ concentration, the lowest value was $8.16 \pm 0.43 \%$ in $n$-hexane extract 100 $\mu \mathrm{g} / \mathrm{mL}$ concentration.

Table 4. Iron (II) ions chelating activity of of the extracts obtained from O. europea leaves

\begin{tabular}{|c|c|c|c|c|}
\hline \multirow[t]{2}{*}{ Extracts } & \multicolumn{4}{|c|}{$\begin{array}{c}\text { Iron (II) ions chelating activity } \\
\text { (Inhibition } \% \pm \text { SEM) }\end{array}$} \\
\hline & $100 \mu \mathrm{g} \mathrm{mL}-1$ & $250 \mu \mathrm{g} \mathrm{mL}-1$ & $500 \mu g \mathrm{~mL}^{-1}$ & $1000 \mu \mathrm{g} \mathrm{mL}-1$ \\
\hline n-Hexane & $8,16 \pm 0,43^{e}$ & $8,95 \pm 0,14^{\mathrm{d}, \mathrm{e}}$ & $9,05 \pm 0,20^{\mathrm{d}, \mathrm{e}}$ & $8,85 \pm 0,18 \mathrm{~d}, \mathrm{e}$ \\
\hline Ethyl acetate & $14,87 \pm 1,22^{\mathrm{c}, \mathrm{d}, \mathrm{e}}$ & $16,91 \pm 5,22^{b, c, d, e}$ & $25,62 \pm 5,90^{\mathrm{b}}$ & $50,53 \pm 5,53^{a}$ \\
\hline Methanol & $11,61 \pm 0,24 \mathrm{~d}, \mathrm{e}$ & $15,33 \pm 0,20 \mathrm{c}, \mathrm{d}, \mathrm{e}$ & $17,70 \pm 0,33^{b, c, d}$ & $23,26 \pm 0,31^{b, c}$ \\
\hline
\end{tabular}

As shown in Table 5, the superoxide radical scavenging activity was detected $72.00 \pm 1.35 \%$ in ethyl acetate extract $(250 \mu \mathrm{g} / \mathrm{mL})$, the lowest value as
$13.76 \pm 2.24 \%$ in $\mathrm{n}$-hexane extract at $500 \mu \mathrm{g} / \mathrm{mL}$ concentration.

Table 5. Superoxide radical scavenging activity of the extracts obtained from O. europea leaves

\begin{tabular}{|c|c|c|c|c|}
\hline \multirow[t]{2}{*}{ Extracts } & \multicolumn{4}{|c|}{$\begin{array}{l}\text { Superoxide radical removal activity } \\
\text { (Inhibition } \% \pm \text { SEM) }\end{array}$} \\
\hline & $100 \mu \mathrm{g} \mathrm{mL}^{-1}$ & $250 \mu \mathrm{g} \mathrm{mL}-1$ & $500 \mu \mathrm{g} \mathrm{mL}-1$ & $1000 \mu \mathrm{g} \mathrm{mL}^{-1}$ \\
\hline$n$-Hexane & $13,76 \pm 2,24^{\mathrm{f}}$ & $31,53 \pm 1,97 \mathrm{e}$ & $39,96 \pm 3,52^{\mathrm{d}}$ & $51,02 \pm 0,46^{c}$ \\
\hline Ethyl acetate & $70,78 \pm 2,99 a$ & $72,00 \pm 1,35^{\mathrm{a}}$ & $63,88 \pm 1,65^{\mathrm{a}}$ & $67,29 \pm 2,23^{a}$ \\
\hline Methanol & $59,02 \pm 2,51^{\mathrm{a}, \mathrm{b}}$ & $56,90 \pm 0,85^{b}$ & $67,02 \pm 1,47 \mathrm{a}$ & $68,82 \pm 0,65^{\mathrm{a}}$ \\
\hline
\end{tabular}


Finally, according to the results while the highest value in the reduction capacity of extracts was found $1.49 \pm 0.03$ in methanol extract at $1000 \mu \mathrm{g} / \mathrm{mL}$ concentration and the lowest value was in ethyl acetate extract $(100 \mu \mathrm{g} / \mathrm{mL})$ (Table 6).

Table 6. Reduction capacity of the extracts obtained from O. europea leaves

\begin{tabular}{|c|c|c|c|c|}
\hline \multirow{2}{*}{ Extracts } & \multicolumn{4}{|c|}{$\begin{array}{l}\text { Reduction capacity } \\
\text { (Absorbance } \pm \text { SEM) }\end{array}$} \\
\hline & $100 \mu \mathrm{g} \mathrm{mL}^{-1}$ & $250 \mu \mathrm{g} \mathrm{mL}^{-1}$ & $500 \mu \mathrm{g} \mathrm{mL}^{-1}$ & $1000 \mu \mathrm{g} \mathrm{mL}^{-1}$ \\
\hline n-Hexane & $0,25 \pm 0,01 \mathrm{e}, \mathrm{f}$ & $0,23 \pm 0,02^{\mathrm{e}, \mathrm{f}}$ & $0,24 \pm 0,01 \mathrm{e}, \mathrm{f}$ & $0,28 \pm 0,00^{\mathrm{d}, \mathrm{e}}$ \\
\hline Ethyl acetate & $0,19 \pm 0,01^{\mathrm{f}}$ & $0,25 \pm 0,01 \mathrm{e}, \mathrm{f}$ & $0,21 \pm 0,00^{d}$ & $0,44 \pm 0,01^{c}$ \\
\hline Methanol & $0,33 \pm 0,00^{d}$ & $0,54 \pm 0,01^{b}$ & $0,90 \pm 0,04 a$ & $1,49 \pm 0,03 a$ \\
\hline
\end{tabular}

To determine the oleuropein concentration in the extracts, HPLC analysis was used. In order to determine the oleurpeins's concentration in all extracts, calibration curve and the equation were first proved by using oleuropein as reference compound. Retention time was recorded as $9.1 \pm 3 \mathrm{~min}$ for the oleuropein. The reference oleuropein and the all extracts were inoculated respectively to confirm if the detected major peak is oleuropein or not. The repetitive increase in the area of the same peak confirmed the idea that the major peak was oleuropein in the methanol extract. Thus, it has been measured that $1 \mathrm{~g}$ of methanol extract contains 24.12 $\pm 2.87 \mathrm{mg}$ of oleuropein.

\section{DISCUSSION and CONCLUSSION}

In the current study, it was recorded that the yield of extraction of olive leaves of the Memecik cultivar was $34.59 \%$ in methanol, $26.15 \%$ in ethyl acetate and $13.21 \%$ in $n$-hexane extracts. Orak et al. (2019) reported the yield of olive leaf extracts varied from $24.26-29.87 \%$ and also the yield of methanol extract of Memecik type was found at the level of $27.11 \%$. In addition, the oleuropein in methanol extract was determined as $24.12 \pm 2.87 \mathrm{mg} / \mathrm{g}$ in this study. The result obtained for oleuropein in the methanol extract is in accordance with previous report which state that oleuropein, the main phenolic component for all genotypes, range from 21.0 to $98.0 \mathrm{mg} / \mathrm{g}$ in the methanolic extract (Orak et al. 2019). Orak et al. (2019) reported that oleuropein found at $38.2 \pm 1.9$ for the methanol extract of Memecik type olive leaf. Moreover, hydroxytyrosol, verbascoside, luteolin 7-Oglucoside and luteolin 4'-O-glucoside have been widely contained in olive leaves (Talhaoui et al. 2015).

The maximum amount of total phenolic substances was determined as $85.27 \pm 15.03$ in methanol extract $(1000 \mu \mathrm{g} / \mathrm{mL})$, the lowermost value was found as $0.18 \pm 1.32 \mathrm{mg}$ gallic acid (GAE) / g in $n$-hexane extract $(500 \mu \mathrm{g} / \mathrm{mL})$. This value in the methanol extract was found to be lower than $209 \pm 3.4 \mathrm{mg}$
GAE/g reported by Orak et al. (2019) for Memecik cultivar olive leaf. Orak et al. (2019) described that total phenolic substances was found as a $110-268 \mathrm{mg}$ $\mathrm{GAE} / \mathrm{g}$ in the methanol extract of leaves of other Olea species growing in Turkey. These differences stem from cultivated conditions, natural habitats of the olive tree.

In this study, the highest value in the DPPH radical scavenging activity was measured $72.93 \pm 0.42 \%$ for ethyl acetate extract at $500 \mu \mathrm{g} / \mathrm{mL}$ concentration and the lowest value was $13.77 \pm 1.23 \%$ in $n$-hexane (100 $\mu \mathrm{g} / \mathrm{mL}$ ). Addition, it was found in this study that when the concentration of extracts in methanol, ethyl acetate and $n$-hexane groups decreased, DPPH radical scavenging activity was found to decreasing accordingly. Hayes et al. (2009), olive leaf methanol extract DPPH radical scavenging activity increased from $100 \mathrm{ppm}$ to $400 \mathrm{ppm}$ and this increase reached $94 \%$ at $1000 \mathrm{ppm}$. Our results were consistent with these reported results. Stupans et al. (2002) reported that this activity was due to hydroxytyrosin and oleuropein, a radical scavenging agent in olive leaves. Non-enzymatic lipid peroxidation caused by free radicals begins with lipid peroxidation of $\mathrm{H}$ atoms containing an electron from conjugated double bonds in fatty acids and the fatty acids in the membrane are converted to lipid free radicals. These radicals are unstable and are converted to oxygen by lipid peroxide radical (LOO) and then by electron from other fatty acids to lipid peroxides $(\mathrm{LOOH})$. Malondialdehydes are orginated as a result of peroxidation of fatty acids while chaining continues (Halliwel and Gutterigde 1990). In our study, the highest value linoleic acid reduction was found as $89.52 \pm 9.77 \%$ in methanol extract at $250 \mu \mathrm{g} / \mathrm{mL}$ concentration, the lowest value as $61.19 \pm 4.05 \%$ in ethyl acetate extract at $100 \mu \mathrm{g} / \mathrm{mL}$ concentration. Danahaliloğlu et al. (2018) found that the \% inhibition values in the methanolic extract of the Halhalı type olive leaf ranged between 72.89-41.32\%. The highest value in reduction of iron (II) ions was found as $50.53 \pm 5.53 \%$ in ethyl acetate at 1000 
$\mu \mathrm{g} / \mathrm{mL}$ concentration, the lowest value as $8.16 \pm 0.43 \%$ in $n$-hexane $100 \mu \mathrm{g} / \mathrm{mL}$ concentration. Hayes et al. (2009) reported that iron chelating activity was found in methanolic extracts as ellagic acid $>$ sesamol $>$ olive leaf extract $>$ lutein, respectively.

It is known that superoxide dismutase (SOD) is a key antioxidant enzyme and catalyses the dismutation of the superoxide $\left(\mathrm{O}_{2}^{-}\right)$radical into eithermolecular oxygen $\left(\mathrm{O}_{2}\right)$ or hydrogen peroxide $\left(\mathrm{H}_{2} \mathrm{O}_{2}\right)$. SOD has three isozymes as Mn-SOD, Fe-SOD and CuZnSOD, which localized in different cell compartments of olive leaf (Corpas et al. 2006; Halliwell et al. 2000). According to our findings, the highest superoxide radical scavenging activity was found $72.00 \pm 1.35 \%$ in ethyl acetate extract $(250 \mu \mathrm{g} / \mathrm{mL})$, and was measured the lowest value as $13.76 \pm 2.24 \%$ in $n$-hexane extract $(500 \mu \mathrm{g} / \mathrm{mL})$. Lee and Lee (2010) reported that SOD activity was determined at $18 \%$ in oleuropein of olive leaves, $67 \%$ in routine, $83 \%$ in caffeic acid and $19 \%$ in their mixtures. Finally, the highest reduction capacity was found $1.49 \pm 0.03$ in methanol extract $(1000 \mu \mathrm{g} / \mathrm{mL})$ and the lowest value was $0.19 \pm 0.01$ in ethyl acetate extract $(100 \mu \mathrm{g} / \mathrm{mL})$ in our study. Danahaliloğlu et al. (2018) reported that FRAP values for methanol extracts of olive leaves of Halhali type were between 0.96-0.11.

Various antioxidant activity differences observed in the olive leaf extracts are thought to be due to the level of polyphenolic compounds passing into the solvent used and the difference in their chemical structure. Considering the extracts according to polarity, it was found that phenolic substances dissolved in methanol extract alone or together synergistically reduce free radicals, chelate metal ions, prevent lipid peroxidation and have metal-reducing capacities.

As a result, it was determined that the methanolic extract of olive leaf was found to be more active than other extracts in terms of total phenolic substances, linoleic acid reduction and reduction capacity. Considering this study data, where the antioxidant activities of olive leaves in different extracts were determined, it was concluded that olive leaf might be regarded as a natural alternative antioxidant source in food, cosmetics, pharmaceutical and animal nutrition fields.

\section{ACKOWLEDGEMENT}

\footnotetext{
\# This thesis research was supported by funds from 'The Scientific Research Council of Afyon Kocatepe University (AKU BAPK, Project No: 18.SAG.BIL.30, Thesis no: 2019-042). Also this study was presented as a poster presentation at ' 2 nd International Conference on "Veterinary Biochemistry and Clinical Biochemistry: Advances and Challenges in Understanding the Mechanism of Diseases", 24-26 October 2019, Ankara, Turkey.
}

Conflict of Interest: The authors declare that they have no conflict of interest

\section{REFERENCES}

Ansari M, Dianat S, Kazemipour M, Adib N. Simple HPLCUV method for the determination of oleuropein in Olea europaea L. leaves extract and pharmaceutical preparations. National Biotechnology Conference. AAPS J. 2006; 8: 002590 .

Barbora B, Toietta G, Maggio R, Arciello M, Tarocchi M, Galli A, Balsano C. Effects of the olive-derived polyphenol oleuropein on human health. International Journal of Molecular Sciences. 2014; 15: 18508-18524.

Benavente-García O, Castillo J, Lorente J, Ortuño A, Del Rio JA. Antioxidant activity of phenolics extracted from Olea europaea L. leaves. Food Chem. 2000; 68: 457-462.

Blois, MS. Antioxidant determinations by the use of stable free radical. Nature. 1958; 181: 1199-1200.

Botsoglou E, Govaris A, Ambrosiadis I, Fletouris D. Lipid and protein oxidation of $\alpha$-linolenic acid-enriched pork during refrigerated storage as influenced by diet supplementation with olive leaves (Olea europea L.) or $\alpha$ tocopheryl acetate. Meat Sci. 2012; 92: 525-532.

Botsoglou E, Govaris A, Ambrosiadis I, Fletouris D, Papageorgiou G. Effect of olive leaf (Olea europea L.) extracts on protein and lipid oxidation in cooked pork meat patties enriched with n-3 fatty acids. J. Sci. Food Agric. 2014; 94(2): 227-234.

Chen X, Ahn DU. Antioxidant activites of six natural phenolics against lipid oxidation induced by $\mathrm{Fe}^{2+}$ or ultraviolet light. Journal of the American Oil Chemist's Society. 1998; 75: 1717-1721.

Corpas FJ, Fernandez-Ocana A, Carreras A, Valderrama R, Luque F, Esteban FJ, Rodriguez-Serano M, Chaki M, Pedrajas JR, Sandalio LM, Del Rio LA, Barroso JB. The espression of different superoxide dismutase froms is cell-type dependent in olive (Olea europaea L.) leaves. Plant Cell Physiol. 2006; 47(7): 984-994.

Chen HY, Lin YC, Hsieh CL. Evaluation of antioxidant activity of aqueous extract of some selected nutraceutical herbs. Food Chemistry. 2007; 104: 1418-1424.

Danahaliloğlu H, Tekeli Y, Göygıncık S, Yıldırım F. Hatay'da farkli bölgelerde yetiştirilen zeytin yapraklarının antioksidan özelliklerinin belirlenmesi. Karadeniz Fen Bilimleri Dergisi. 2018; 8(1): 77-86.

Dekanski D, Jani'Cijevi'C-Hudomal S, Tadi'C V, Markovi'C G, Arsi'C I, Mitrovi'C DM. Phytochemical analysis and gastroprotective activity of an olive leaf extract. Journal of the Serbian Chemical Society. 2009; 74(4): 367-377.

Dinis TCP, Madeira VMC, Almeida LM. Action of phenolic derivatives acetaminophen, salicylate, and 5aminosalicylate) assay inhinitors of membrane lipid peroxidation and assy peroxyl radical scavengers. Archives of Biochemistry and Biophysics. 1994; 315(1): 161-169.

Ferreire ICFR, Barros L, Soares ME, Bastos ML, Pereira JA. Antioxidant activity and phenolic contents of Olea 
europaea L. leaves sprayed with different copper formulations. Food Chemistry. 2007;103: 188-195.

Halliwell B, Clement MV, Long LH. Hydrogen peroxide in the human body. FEBS Letter. 2000; 486: 10-13.

Keser O, Bilal T. Zeytin sanayi yan ürünlerinin hayvan beslemede kullanım olanakları. Hayvansal Üretim. 2010; 51(1): 64-72.

Kristakis AK. Olive oil from tree to the table. Second edition, Food \& Nutrition Pres. Inc. 2nd. 1998; pp: 3-47.

Lee $\mathbf{O H}$, Lee BY. Antioxidant and antimicrobial activities of individual and combined phenolics in Olea europaea leaf extract. Bioresource Technology. 2010; 101:3751-3754.

Nishikimi M, Rao NA, Yagi K. The occurance of superoxide anion in the reaction of reduced phenazine methosulfate and molecular oxygen. Biochemical and Biophysical Research Communications. 1972; 46(2): 849-854.

Omar SH. Oleuropein in olive and its pharmacological effects. Sci Pham. 2010; 78: 133-154.

Orak HH, Karamac M, Amarowicz R, Orak A, Penkacik K. Genotype-related differences in the phenolic compound profile and antioxidant activity of extracts from olive (Olea europaea L.) leaves. Molecules. 2019; 24: 1130.

Oyaizu, M. Studies on product of browning reaction prepared from glucose amine. Japan Journal of Nutrition. 1986; 44: 307-315.

Pan Y, Zhang X, Wang H, Liang Y, Zhu J, Li H, Zhang Z, Wu Q. Antioxidant potential of ethanolic extract of Polygonum cuspidatum and application in peanut oil. Food Chemistry. 2007;105: 1518-1524.

Rodrugues F, Pimentel FB, Oliveira MBPP. Olive byproducts: Challenge application in cosmetic industry. Industrial Crops and Products. 2015; 70: 116-124.

Silva S, Gomes L, Leitao F, Coelho AV, Vilas Boas L. Phenolic compounds and antioxidant activity of Olea europaea L. fruits and leaves. International Food Science and Techonology. 2006; 12: 385-396.

Somova LI, Shode FO, Ramnanan P, Nadar A. Antihypertensive, antiatherosclerotic and antioxidant activity of triterpenoids isolated from Olea europaea, subspecies africana leaves. J Ethnopharmacol. 2003; 84: 299-305.

Souilem S, Fki I, Kobayashi N, Khalid N, Neves M, Isodi S, Nakajima M. Emerging technologies for recovery of value-added components from olive leaves and their applications in food/feed industries. Food and Bioprocess Technology. 2017; 10(2): 229-248.

Spinelli R, Picchi G. Industrial hervesting of olive tree pruning residue of energy biomass. Bioresource Technology. 2010; 101: 730-735.

Stupans I, Kirlich A, Tuck KL, Hayall PJ. Comparison of radical scavenging effect, inhibition of microsomal oxygen free radical generation, and serum lipoprotein oxidation of several natural antioxidants. Journal of Agriculture and Food Chemistry. 2002; 50: 2464-2469.

Talhaoui N, Taamalli A, Gómez-Caravaca AM, FernándezGutiérrez A, Segura-Carretero A. Phenolic compounds in olive leaves: Analytical determination, biotic and abiotic influence, and health benefits. Food Research International. 2015;77: 92-108.

Wojdylo A, Oszmianski J, Czemerys R. Antioxidant activity and phenolic compounds in 32 selected herbs. Food Chemisrty. 2007;105(3): 940-949. 